\title{
FROM MOBILITY TO "EXILE". SHIFTING CO-PRESENCE: NARRATIVES OF BULGARIAN-SYRIAN FAMILIES IN BULGARIA
}

\author{
Desislava Pileva \\ Assistant Professor \\ Institute of Ethnology and Folklore Studies with Ethnographic Museum \\ Bulgarian Academy of Sciences \\ Sofia, Bulgaria \\ Email: desislava.pileva@iefem.bas.bg
}

\begin{abstract}
The article addresses the topic of shifting co-presence of four BulgarianSyrian families living in Bulgaria with their Syrian kin. Since the dividing line is the beginning of the conflict in Syria, the body of the text consists of two sections: the first one regards the physical co-presence before and the second one presents the virtual co-presence after. The notion before also refers to the free movements between "here" (Bulgaria) and "there" (Syria), and after encompasses the time of the peculiar "exile" of the mixed families who were deprived of the possibility to travel and to be bodily present. Therefore, the shift is shown by analysing the essence of the face-to-face and from-distance communication within the context of changing lifestyle circumstances.
\end{abstract}

Keywords: co-presence, exile, family/kin ties, ICT, mobility, Syria, visits

Being co-present with someone can often be taken for granted. Every day we meet, greet and communicate with different people, some of whom are dear to us, and for others we just have to be around. Sometimes we have the freedom to choose for ourselves with whom, when, how, and for how long we want to be co-present, to get and stay in touch over time and distance. In other cases, however, choosing is not an option - our communication patterns are shaped and dependent on factors outside of our own control, such as political circumstances, technologies, etc. Both of these alternatives concern many Bulgarian-Syrian families in Bulgaria. They used to be able to set their own manner of being copresent with their Syrian kin, regardless of time and distance, and nowadays these couples and their offspring have to find their (new) ways for maintaining personal connections with their relatives who live away from them. 
As Maruška Svašek (2008: 214) claims, migration "almost unavoidably ... moves individuals in alternative ways". Various meanings can be ascribed to this statement, placed in different contexts, and hence it may have many interpretations. However, here it is considered in the context of years-long process of movements between countries and homes, in different directions for different periods of time, under different circumstances, which were inevitably but also unforeseeably discontinued, leaving fewer alternatives for being co-present. In this respect, how did the mixed families manage their presence within the movement then? How do they adapt to the shift, or shift their adaptation now?

\section{RESEARCH APPROACH AND METHODOLOGY}

\section{Approach}

The topic of the article is analysed through the prism of two patterns of copresence - physical and virtual (Baldassar 2008). The former suggests simultaneous bodily presence of all parties, particularly family/kin members, at one place. Hence, in the context of migration, the boundaries between physical presence and absence can be diminished by visits. On the one hand, being physically co-present is essential for maintaining immediate face-to-face and "body-to-body" contacts with the longed-for people. It allows the family/kin members to "read" each other's minds to "hear 'first hand' ... to sense directly their overall response, to undertake at least some emotional work" (Urry 2003: 163-164). The direct communication without intermediation (of people, devises, etc.) provides (more) genuine interactions, more or less eliminating one's chance to selectively present information.

On the other hand, by being physically co-present in Syria, one can "face the place" (e.g. the birth place), which also enables them to "face the moment" by participating in various daily activities and special events with the family (Boden \& Molotch 1994; Urry 2002; Mason 2004). This way, not only the local marital partners (the Syrians), but also their mixed families have the perception of being (and are accepted as) an integral part of the kin. Therefore, striving for such close face-to-face interactions is provoked by a mutual longing for each other; it is driven by "kinship ties" and "cultural codes of behaviour" which give all family members a unique feel of intimacy (Stephenson 2002: 393; Svašek 2008: 219). Spending time together allows all parties, as Mason (2004: 424) argues, "to build up a history of having known each other over time, and to acquire mutual and shared knowledge of each other ... sustained in between times in more virtual ways, over distance". Later on, when the mixed families 
return to Bulgaria, some of the recollections of the meetings and events in Syria turn into both carriers and triggers of memories for emotional encounters (Svašek 2008: 218). These statements became exceptionally valid after the mixed families were deprived of safely visiting the Syrian kin, when their manner of co-presence (greatly) shifted.

The unrest in Syria, which in 2011 escalated into an armed conflict with many factions, made the physical distance between the Bulgarian-Syrian families living in Bulgaria and many of their Syrian kin members constant. Therefore, they all needed to find alternative ways of "being together" across distance and time. The rapid development of the information and communications technology (ICT) greatly facilitates coping with the new situation of physical separation, allowing them to get and stay in touch regularly. The mixed families have established their own communication patterns with their loved ones. However, the manners of maintaining connection are determined by the family/ kin members' personal needs and technology literacy, as well as some "family norms and obligations" (Nedelcu \& Wyss 2016: 203). This way, relatives from all over the world can create connected lifestyles together across space. Urry (2002: 265-269) calls that "virtual proximity", and Baldassar (2008: 253-256) determines it as "virtual co-presence".

According to Licoppe (2004: 135-136), via ICT people physically separated may create "contentious patterns of mediated interactions that combine into 'connected relationships"'. Therefore, social relations transform under the influence of developing tools for communication (ibid; Licoppe \& Smoreda 2005). As Nedelcu and Wyss (2016: 206) claim, new ICT tools "complement rather than substitute" the existing ones, widening opportunities for relatives to stay connected. Hence, the internet and social media become the only direct, though from distance, manner for immediate, unmediated, even face-to-face contact with the longed-for people living away. Everyday communication allows family/kin members to discuss socio-political topics, make decisions together on important issues, and talk / exchange messages regarding "nothing particular" (Wilding 2006: 131).

Considering all of the above, the aim of the article, on the one hand, is to discuss aspects of the Bulgarian-Syrian families being together with the Syrian kin before the beginning of the armed conflict, and on the other, to show some of the transformations the manner of being co-present has been going through after - during the last decade.

Throughout the text the notion "mixed" is used for describing the families. It is chosen as unifying in terms of bicultural, bilingual, and bi-religious, as well as cross-national marital couples (cf. Breger \& Hill 1998; Vinea 2007; Edwards \& Caballero \& Puthussery 2010; Lopez 2017). The latter refers to marriages 
between external partners, both of whom keep their birth citizenship and maintain connection with their native country, regardless of the place of residence (Cottrell 1990: 152). The terms "here" and "there" are also used; "here" as a synonym for Bulgaria (the place of permanent residence) and "there" - for Syria (the migrants' country of origin which in one way or the other is present within the mixed families' lives). These definitions were also used by my interlocutors during the conversations for geographically distinguishing both countries.

\section{Methodology}

The Bulgarian-Syrian families' sample is a part of a bigger study of mixed families I have been carrying out for the last five years. This text is based on first-hand ethnographic data, gathered through in-depth interviews, some of them face-to-face, and others online via Facebook or Skype (the interlocutors chose the manner most suitable for them). The participants were found either through the mediation of a common acquaintance, or thanks to another interviewee of mine. The conversations were carried out with one or two of the family members, a partner, and an adult child, on separate occasions. This allows to scrutinize different points of view about the same research topic and to supplement and compare the gathered information.

The article focuses on four couples consisting of a Syrian man and a Bulgarian woman. The Syrians came to Bulgaria in the 1970s and 1980s in order to receive higher education in various fields. ${ }^{1}$ Their Bulgarian spouses also have university education received in their native country. One of the couples got married in the 1980s and the rest - in the 1990s. Two of the families have one child and the other two - two children. The offspring of mixed descent are between the age of 8 and 39 .

These particular families were chosen because of the significant amount of time they used to spend in Syria. Their way of life before the war was characterized both by settlement for a certain period or periods of time "there" and establishment of a manner of mobility "in-between" the two countries by executing organized systematic travels back and forth. On the one hand, this helped the migrants to preserve a palpable connection with the birth family. On the other, it allowed their spouses and children to become a part of the life "there" on a daily basis, and an integral part of the extended family as well. The possibility of frequent face-to-face contacts and personal visits, even residence in Syria, used to help all the members of the mixed families to "feel the presence of people and places involving all of the five senses" (Baldassar 2008: 252). As a result, they developed a strong and long-lasting relationship with their kin 
and a connection with the country and the culture. However, after the beginning of the Syrian conflict the circumstances allowing these visits underwent (drastic) transformations. They not only interrupted the families' travels, but also changed the manner of communication within the dispersed kin.

\section{CO-PRESENCE BEFORE}

In most of the cases Syrians had very few or close to no visits to their home country during their student years "here". Therefore, the Syrians' first travels to their homeland and birth family in a long time were around the time they decided to get married. Hence, the couples' first visits "there" were inspired by the relationship itself, and sometimes were even initiated by their Bulgarian partners. In this respect, their main purpose for the women was to establish a personal relationship with their spouse's kin, so they all could start to get to know each other and really "see" each other.

However, in a certain season of the four families' lives, Syria became the dwelling destination, the country where both of the partners could develop professionally and even raise their children. None of the couples had considered settling down elsewhere in the country than in the Syrian partner's hometown. Therefore, they were seeking both to be co-present for their kin and to have relatives around on a daily basis. Through intense face-to-face communication, the relationship between the actors was unfolding in several aspects. In the next paragraphs, I will briefly present the life stories of the four families ${ }^{2}$ regarding migration and mobility as lifestyle decisions.

After graduating from university and the birth of their first child, in 1996, the spouses of the first family (married in 1993) decided to move to Fayyaz' hometown in Syria. The particular occasion was his moving into the barracks, considered compulsory by the state. "There" the family resided along with the husband's parents and unmarried siblings. After Fayyaz had left the barracks two and a half years later, the family (already of four) decided to stay in Syria for a little longer. Both partners tried to establish their own private dental and psychologist practices in order to gain financial independence of Fayyaz' father and to move out of the parental house. However, in 2000, due to some financial difficulties in the entire Syrian family, which also affected Fayyaz and Irena, the couple decided return to Bulgaria.

The second family (married in 1980) left for Syria in 1985, after Arif had managed to pay off his military service. The couple and their four-year-old daughter settled in a flat within a residential building, which had separate rooms for a medical office. In this case, unlike the rest, the decision to migrate was 
mostly the husband's. Arif hoped that developing professionally and achieving financial stability should have been enough to convince Magda to stay "there". However, for the Bulgarian wife, the physical absence of her birth family was emotionally difficult to deal with. Therefore, she spent most of the next four years residing with her parents and daughter in Bulgaria, and he - travelling intensively between the countries. Consequently, finding this situation unsuitable, in 1989 the family settled down in Bulgaria permanently.

The Syrian partner of the third couple (married in 1996) had to drop out of medical school due to some financial difficulties of his birth family. However, Asif decided to stay in Bulgaria, where later on he established an import/export business. The couple's first visit to Syria was in 1994, before they got married. The occasion for the stay, which lasted a few months, was the trading business he had at the time between some countries in the region and Bulgaria. About six years later, in 2001, Asif and Svetla returned along with their five-year-old son. Then their intention was to settle down "there" permanently, developing their international trading business, and living in their own apartment within the premises of Asif's parents. However, in a few years' time, Asif found it hard to re-adapt after having lived away for twenty years, therefore the family returned to Bulgaria.

The husband of the fourth family (married in 1998), like in the previous case, decided to stay and work in Bulgaria while still at university. However, in 1994, a couple of years after Jamal had met Jasmin, and some time before they got married, both of them went to Syria for a year. The travel was initiated by Jasmin, in order to become more familiar with the kin and the socio-cultural specificities before getting married. Shortly after their wedding in 1998, they established their second architectural bureau, this time in Jamal's hometown. Therefore, during the next decade or so the couple set up a peculiar manner of mobile life between Bulgaria and Syria, turning both countries into places of residence and professional development, as well as into homelands. However, they were planning for a permanent settlement in Syria, after the birth of their children.

In spite of the reasons for leaving Syria, none of the first three couples discontinued their co-presence "there". After the remigration to Bulgaria, the physical distance between the mixed families and the Syrian kin was somehow compensated by the new routine of mobility they all set. Based on opportunities and personal preferences of the mixed families, the frequency and the duration of the stays varied from yearly visits for a couple of months to travels every other year for a few weeks. However, while the children were of school-age, the travels were strictly coordinated with their summer vacations. This allowed the offspring and the parents to be co-present "there" as long as possible without 
interfering with the family's lifestyle "here". During their visits, each couple stayed in the home where they used to live.

Among all, the first family's travelling routine was the most regular and the duration of the stays the most structured. For ten years Fayyaz and Irena and their two daughters (b. 1993, 1998) were making well-planned annual visits. As the elder daughter stated, "my sister and I visited for three months ... One of our parents took us there and usually stayed for two weeks, the other - came to get us and stayed for two weeks" (personal communication 2017). They never deviated from this routine, since no other period of the year allowed such a long stay "there".

The same also goes for the third family. Asif and Svetla were somehow duplicating the travel model they had established while residing in Syria when they spent the summer in Bulgaria, being co-present with the Bulgarian kin. After their move to the wife's home country, the couple managed to maintain annul visits to Syria for at least one month during the summer vacation of their son (b. 1996).

After their not-so-successful attempt to settle in Syria, the second family tried to find the most suitable and convenient way to be physically co-present with the husband's relatives. For a decade following their final settlement in Bulgaria, Arif and Magda visited Syria once in two years for a few weeks in the summer. This regularity was strictly followed while their daughter (b. 1980) was in school. However, when their only child went to university and especially after she left for Germany to continue her studies, the travels took place once in a while.

As to the fourth couple's co-presence, it could be determined as somewhere in-between the two countries. However, their manner of travelling also had its variations. For most of the time, there were no specific reasons for Jamal and Jasmin's habitat and the length of their stays "here" and "there", other than their work commitments. However, between 2008 and 2010, the spouses deliberately dwelled in Bulgaria, because of Jasmin's pregnancy and the birth of the couple's first child. This event was supposed to be the awaited turning point for the family's permanent settlement in Syria.

Generally, the purposes for dwelling "there", along with the visits afterwards could be considered routine according to Baldassar, Baldock, and Wilding's (2007: 139-140) classification. On the one hand, the striving for better career developments of the spouses by establishing private practices/businesses in Syria was among the motives. However, this distinction is rather conditional, since in order for all of them to reside "there" (or wherever) and to be financially independent (from whomever), employment was needed. In some cases, the maintenance of professional and investment responsibilities regulated the 
frequency of (some of) the visits. For instance, Asif had been running various trading businesses related to Syria and the Middle East region ever since the early 1990s. In this respect, until 2010 he had travelled to his home country and town alone numerous times for different periods. Meanwhile, however, he was able to logistically arrange the residence of his mixed family "there" in the early 2000s. Namely, aiming at settling permanently in Syria, Jamal and Jasmin had been maintaining their architectural bureau in his hometown for about a decade before the war. Throughout this time, both partners together were routinely travelling, as they stated, "sometimes twice a month" (personal communication 2016), between the two countries. Therefore, they were dwelling "within mobility" where "home is no longer one place. It is locations" (Hooks 1991 [1990]: 148; see also Urry 2002: 257-258).

On the other hand, choosing to go back to the hometown and to live along with or nearby the birth family made the striving for physical co-presence with the kin and/or the native place the most essential purpose for dwelling "there". Consequently, the Syrian partners were able to re-establish their direct communication with the birth family on daily and special-occasion basis. Although it was possible for the spouses to go back to their country of origin, they did not "go back" to their life before the migration. They had to adapt to the "new" socio-cultural environment and family/kin situation. At the same time, the Bulgarian partners and the children of mixed descent had the chance to develop close personal relationships with their Syrian relatives without mediation of some sort. ${ }^{3}$

Whether the couples were maintaining professional responsibilities or family/kin ties, all of them had enough time and opportunities to create their own daily routine of being co-present "there". The active face-to-face communication facilitated the mutual acquaintance of all actors, allowing them to adjust to each other's characters and specifics. In this respect, the more or less direct co-habitation with the relatives allowed the mixed families to be present and to participate in various socio-cultural practices and events, such as daily home organization, exchanged social visits, feasts, etc. Therefore, the couples, their offspring, and the Syrian kin had the chance to be co-present with each other in several manners.

The co-habitation made the mixed couples a more cohesive part of the kin on a daily basis. In the context of Petridou's (2001: 88) statement that a place acquires its meaning of home through practices, the Syrian husbands engaged in some activities, such as tea drinking every evening, which gave them the feeling of being "at home" (see also Rapport \& Dawson 1998: 9). This way they were co-present with their fathers and brothers, just like in the old times before leaving for Bulgaria. 
The co-habitation also gave the wives (and the children) another cultural perspective. For example, for Svetla one of the most memorable practices of the Syrian kin was the daily family lunch. "Lunch is very important for them. The everyday two-hour-long meal preparation was very stressful for me," she said, laughing (personal communication 2019). On the one hand, the process of food preparation was a form of being together, the time when all women of the kin gathered in the parental kitchen area. On the other hand, eating together was one of the strongest examples of the family's physical co-presence on a daily basis. It was a well-established and cherished practice, the highlight of the day for the women, children, and the men who were able to be home at lunchtime.

Aside from the daily manner of spending time together, there were some special occasions, such as feasts. The co-habitation allowed the couples and their offspring to be present and to participate in both familial and social activities (which in some cases took place at the same time), given the large kin group and their broad social circle. Therefore, for the Syrian partners these celebrations were a reminiscence of the past life in the home country. Such were gatherings with family members from all over the country and exchanging visits with relatives, neighbours, and friends for the celebration of $\mathrm{Eid}^{4}$. Another example was the Christian carnival in Jamal's hometown. Although for the Syrian kin visiting it is a general practice, the presence of Jasmin contributed to the experience. Going to the carnival together turned the Syrian relatives into mediators who introduced Jasmin to the local way of celebrating. Co-experiencing gave both the spouses and the kin a new perspective to the occasions and added a new dimension to their co-presence.

Although generally living or just being "there" meant that the couples and their children were co-present with the kin and the place, they did not have/ want to be really present all the time. Hence, though the essence of co-presence is being together, the notion of private space while living and visiting Syria was present in the narratives. The private space of the couples who dwelled on their own differed from that of the families who lived with relatives, which therefore gave them different opportunities. While Jamal and Jasmin could find seclusion within their own home, Asif and Svetla had their own space in the apartment upstairs, in a building where the rest of the kin lived, and Fayyaz and Irena were able to get some privacy only in their own room within the inlaws' (parents') house. Therefore, in some cases the socio-cultural perceptions and communication could cause some rather negative experiences, especially for the Bulgarian partner, for example for Irena, who found it quite hard to cope with the intense presence of her husband's large kin group and their broad social circle. 
His youngest sister and her children came by each week and stayed for a couple of days; it was as if they were living with us ... Neighbours and guests came in all the time, entered the kitchen [without asking for permission], opened the fridge, took whatever they wanted ... it was so weird for me. (Personal communication 2017)

For Irena's cultural perceptions these situations were too awkward, some even unacceptable, such as the notion of 'all doors open during the day', including those of the bedrooms, which became places for social exchange with kin members, friends, and neighbours. This behaviour was breaching her private space. Consequently, however, Irena did some adjustments to her own state of mind and those of the others. On the one hand, the co-habitation in Syria showed her different social boundaries (or lack thereof) along with cultural perceptions, which she eventually understood. On the other hand, she placed some boundaries between herself and the others on a daily basis (like closing her bedroom door whenever she needed to).

So, did seeking of private space mean avoidance of co-presence? I believe the answer is 'no', since the temporal overwhelming of a particular situation or a practice did not lead to the general rejection of social communication or spending time with the relatives. Looking for solitude was simply a part of the process of adjustment to a different socio-cultural environment. It gave the actors time to find their place and role within the kin.

Along with everything stated above, there was another purpose for the regularity of the visits of the first three families, and namely, to "ease the heartache from being separated", a notion that regards the so-called "special visits" (Baldassar \& Baldock \& Wilding 2007: 140-141). However, in this occasion the most important actors were the offspring of mixed descent and the Syrian kin. The visits gave the grandparents a chance and time to assume and preserve a role within the grandchildren's lives and upbringing.

In the case of Fayyaz and Irena's family, it was the main reason for strictly sticking to their travel routine. For the father, his daughters had to have a personal relationship with his birth family. Their summer stays in Syria were a topic of discussion neither between the spouses nor between the children and parents. When the family moved to Syria, their oldest child was a toddler and in about two years their second daughter was born. Therefore, the Syrian kin in general became an important part of both of their upbringing while residing "there". In this respect, later on, when visiting, not only the grandparents, but also the aunts, uncles, and their families took care of the two sisters. The kin's being co-present for the children, even though in a changed manner and not as thoroughly as they used to, was essential for preserving the personal contact. 
The face-to-face communication and physical co-presence of the Syrian kin and the young child of mixed descent was the main purpose for Arif and Magda's travels during the $1990 \mathrm{~s}$. Therefore, the every-other-year visiting routine was disrupted when their daughter went to university. On the one hand, Arif's parents had passed away long before he moved back to Syria in the 1980s, and all his siblings had families. In this sense, he had no moral obligations to take care of anyone of his kin. On the other hand, when the daughter went to live abroad, the parental couple felt more obliged to be around her (and later on, their grandchild) than to be present for both of their kin.

The establishment of a personal contact between the generations was the main purpose for Jamal and Jasmin's visit to Syria in 2009. The family intended to spend some quality time together with the Syrian kin and to travel around the country before settling down "there" for good. However, in a few months' time, Jasmin found out she was pregnant with the couple's second child, which made them return for a while to Bulgaria. Nevertheless, this visit turned out to be the family's last one to Syria.

Although the travels that these four (and many other) families used to take to Syria resulted in just "intermittent moments of physical proximity" (Urry 2002: 258 ) to relatives, special/everyday events, and important/familial places, these visits were essential for maintaining co-presence and relationships. The possibilities for travelling back and forth made coping with distance easier for both the mixed family and the Syrian kin (see also Baldassar \& Baldock \& Wilding 2007: 144; Markov 2019). However, being able to spend time "there", to travel more or less intensively, turned this mobility into something granted. The real importance of the physical co-presence was realised after the visits discontinued (somewhere between 2009 and 2011), when everything changed for all of them. Afterwards the Syrian partners, but also their spouses and children, became "exiled" in a way, since they have not been able to visit the country and their relatives "there" ever since. This new situation was out of their control and an alternative communication adaptation was needed.

\section{CO-PRESENCE AFTER}

In this section I present some examples, marking a few of the changes and modifications within the mixed families' lives after the beginning of the conflict in Syria. As they have not been able to physically visit the Syrian kin, and vice versa, ${ }^{5}$ the four families have had no choice but to stick to other ways for maintaining their relationship throughout the last decade. 
However, communication from distance was not new for the mixed couples and the relatives "there". Syrians have been in contact with their kin back home ever since they were students. Back then, as well as for the next two decades, the ways, frequency, and regularity of communication were quite different. During the 1980s and 1990s, the four men were able to make phone calls about once a month. These were quite regular, needing prior arrangements as to the particular day and hour. Because of the high cost of international calls during this period, the number of relatives with whom migrants were able to talk was limited. They usually preferred to communicate with their parents, who then distributed information from and to other family/kin members.

Nowadays, the physical distance between relatives living in different countries, cities, and even parts of towns is quite easy to overcome. There is a wide range of ICTs for staying in touch from distance (Skype, Facebook, Viber, WhatsApp, and Snapchat). Social media and internet applications allow the exchange of short and long text/voice/video messages, as well as making of free phone/audio-video and conference calls at any time and anywhere. The "social glue", as Vertovec (2004: 220) characterizes the cheap international telephone calls in the migrants-kin relationship, is a perfectly applicable term with regard to the above methods of modern communication. The developing ICTs allow people from all over the world to maintain connection, compensating for "distance and ... geographic separation" (Licoppe 2004: 138-140).

In this respect, when the possibilities to visit Syria safely were taken away, the only direct connection to the kin "there" was through the internet. Since the parents and most of the close family/kin members still remained in their home country, the virtual co-presence became an integral part of the mixed families' lifestyle. According to Baldassar (2008: 253), the frequency and regularity of the communication from distance are determined by "access to reliable and affordable" technologies. In this respect, every kin member "here" and "there" owns a personal smartphone; therefore, they have an affordable tool for getting in touch with each other. However, considering the extraordinary circumstances in Syria, the internet connection is not always reliable. Nevertheless, appropriate timing is also necessary for staying in contact. The partners of all four families are active and working people, therefore, they are not available for frequent and long conversations at any time. The same also applies to some of the Syrian kin, especially the male relatives. However, they all make time for intra-kin communication.

Bearing in mind the dynamic everyday life and the unforeseeable circumstances that may occur "there" at any time, the easiest and most practical way of maintaining a (relatively) regular communication is trough text messages. Although sometimes it may be time-consuming, it does not require real-time 
communication; hence, it allows all parties to participate whenever available and wherever possible. Nevertheless, written communication does not substitute for the direct real-time contact. Although the frequency of audio-video calls via Skype, Messenger, and Viber are sometimes rarer than texting, talking with each other and even seeing each other face to face gives them the closest feeling of physical proximity, although being physically absent. The video connection allows all participants to observe directly each other's facial expressions and even body language, therefore "to read what the other is really thinking" (Urry 2003: 163).

Usually, the online contacts take place daily or weekly. Fayyaz, Asif, and Jamal exchange group or individual messages with their longed-for relatives. Irena, Svetla, and Jasmin also participate in group conversations and have their own individual contacts with some kin members. Virtual communication includes some of the closest Syrian relatives - siblings, cousins and their children, even some representatives of the older generation - parents, uncles, and aunts. However, the access of many elderly people to the new ICTs depends on the younger generation. Therefore, sometimes the communication with the nephews and nieces may prevail over contacts with the parents, such as in the case of Jamal, for instance, whose siblings' children often text him and Jasmin. Fayyaz' parents, however, have no difficulties in using the ICTs and internet applications. "Since my grandparents are there alone ... my grandmother calls almost every night, sometimes even several times a day" (personal communication 2017). Hence, the main daily direct (audio-video) contacts of this mixed family are with the (grand)parents, not the younger generation.

As to Arif, the situation is somewhat different. The kin members he communicates with are his siblings and their families. However, no daily contacts via different ICTs were indicated, such as exchange of casual text messages in group or individual online conversations. This is how Arif described the frequency of contacts with his siblings: "Mostly they initiate the conversations in every two weeks, give or take. Sometimes we make calls ... I usually forget when there is a feast, but they know and call every time" (personal communication 2017). This manner of not-so-frequent communication from distance has always been the case with them; therefore, it is not related to the lack of physical co-presence during the last ten years.

Generally, on the one hand, the parents of the Syrian spouses (when capable), as well as the youngest generation - the siblings' and cousins' children mainly initiate casual conversations. The former prefer calls as the easier and most complete method for information exchange; the latter stick mainly to text messages. On the other hand, communication with the husbands' siblings and cousins is carried out both ways and is initiated by both parties. Regardless 
of the initiators and frequency of the conversations, no particular reason or special occasion is usually needed for getting in touch.

However, the role of the children of mixed descent in the communication is not straightforward. Jamal and Jasmin's children rarely take part in the conversations with their father's relatives. Firstly, it is because of their age (11 and 8), secondly, they have never had the chance to establish direct connection with their Syrian kin, and thirdly, they do not master enough any common language. Therefore, the parents help their children to communicate during some of the audio calls.

Asif and Svetla's son is an adult, he has a common language with his Syrian kin, and has not only met most of his relatives numerous times, but also lived "there" for a while as a child. However, the physical separation during the last decade (while he was a teenager) has marked his relationship with the Syrian kin and led to quite scarce direct communication with them. The same also applies to Arif and Magda's daughter, whose face-to-face contacts with their Syrian relatives diminished about ten years before the conflict "there". Therefore, both parental couples share information regarding their own children, as well as the Syrian family/kin members, distributing it between all parties. ${ }^{6}$

Fayyaz and Irena's daughters differ significantly from the other cases. The regular yearly travels and months-long stays in Syria reflect positively on the personal relationships between the two children and the kin "there". After the discontinuation of the visits, all of them have managed to incorporate the communication-from-distance into their changing lifestyle. Both daughters have daily or weekly contacts via text messages and audio/video calls not only with their grandparents, but also cousins, uncles, and aunts.

The developing ICTs also add an additional functionality to the virtual co-presence - publication or exchange of visual materials. These, just like the text messages, contain diverse information, regarding everyday activities, interesting places, and special occasions, such as feast preparations or celebrations. On the one hand, there are social media texts and visual publications, which may initiate public comments on behalf of some of the longed-for people, regarding expressions of joy or wishes for well-being. For instance, Asif and Svetla's frequent travels between Bulgaria and Sweden (their current country of residence) are usually announced on their Facebook profiles and are often accompanied by visualizations (like a video of being on the road). This activity always receives comments from some Syrian relatives in Arabic. On the other hand, photographs and videos are exchanged in personal/group messages. The correspondences they provoke remain private between the communicating parties, which actually shows the close relationship between particular groups of family/kin members. This way, via their social media accounts and telephone 
apps, the mixed families, including some of the adult offspring, and the Syrian kin are able to travel virtually and to be more present for their loved ones, though being physically separated. Hence, as Wilding (2006: 132) claims, they become "virtual families", who meet in "cyberspace" regularly or occasionally.

However, social media, such as Facebook, are also being used by Jamal and Jasmin, and Fayyaz and Irena as means for making strong civil statements about the war. Both families lost close relatives and friends in the conflict, some of them as civilian casualties, others as soldiers. Thus, Facebook has become a platform where they can show others their side of the story. By posting various graphic videos and photographs from the battlefield (during or after military actions), accompanied by strong statements, they turn their personal accounts into a platform for expressing their thoughts, fears, and anger, even disappointment, disagreement, sadness, longing, and mourning. On the one hand, via the social media they can find/provide support from/to family/kin members and other like-minded people (see also Glick Schiller \& Basch \& Blanc-Szanton 1992: ix; Wilding 2006: 138). On the other hand, this virtual space is used as a way for overcoming the physical distance between "here", where they have to live, and "there", where they cannot be.

Generally, by using the ICTs, dispersed family members are able to "feel and function like a family" (Mahler 2001: 584). Although this applies in a more general manner to the usual communication within transnational families, such indirect contacts bear stronger values under exceptional circumstances. In the current cases, the virtual co-presence secures regular (regardless of the actual duration) exchange of information, ideas, news, or just having small talks between the mixed families "here" and their Syrian kin "there". Therefore, they are not only able to be co-present, but also to co-experience different events with each other over distance and time.

\section{FINAL DISCUSSION}

The sense of longing (and sometimes even the feeling of obligation) for the dispersed kin results in looking for opportunities to stay connected across time and space (cf. Baldassar 2015). In this respect, even the temporal residence in Syria was (partly) a result of the longing for the birth family and the homeland. Later on, the travels to "there" turned out to be physical as well as emotional journeys back to migrants' roots (see also Nguyen \& King 2002: 221; Stephenson 2002: 392), which also constitute an essential part of the mixed families' background. In one way or the other, the visits, regardless of the duration and regularity, affected the couples' and their offspring's lifestyle, and vice versa. By spend- 
ing time in Syria, all families declared their desire to maintain close family/ kin ties, aiming at overcoming the physical distance between them. Therefore, the face-to-face meetings and family gatherings became special "events" on their own, and, being more charged with expectations, they demonstrated the participants' commitment to the relationship (Licoppe \& Smoreda 2005: 327).

In this sense, when the possibility to travel to Syria and to be physically present for the longed-for people was (abruptly) discontinued, the four mixed families found themselves in a peculiar situation. They left the country thinking of going back again next year, or in a few months, as usual. This perception was a manifestation of their comprehension of the visits and the residence "there" as something granted, a movement that was under their control. However, they were left only with other ways for being co-present - mostly virtually. Although communication from distance was not new to the couples and the Syrian kin, being co-present via the ICTs while "away" turned into (almost) the only way for being present at all.

Although I find Urry's claim (2002: 258) that "virtual ... travel will not simply substitute for the corporeal travel, since ... [it] appears obligatory for sustaining social life" to be generally valid, in particular, when it comes to extraordinary circumstances, the virtual co-presence might be the only alternative for maintaining (any) personal connection across distance and time. Hence, the following statement also finds place in this discussion: "now, more than ever before, the proliferation of ICTs and new media environments has begun to challenge the premise that strong relationships require face-to-face interactions" (Baldassar et al. 2016: 135-136).

But still, what about physical co-presence after the beginning of the conflict in Syria? The possibilities for face-to-face communication in person have not been completely eliminated, though they have severely diminished. Since travels to "there" have been impossible, meetings have been taking place outside of the conflict zone, in particular in two European countries, Norway and Sweden - the new settlements of some Syrian kin members who left their homeland after 2011. However, so far only Fayyaz and Asif each have a sibling who migrated along with their families, seeking refuge. ${ }^{7}$ Hence, through more or less intensive face-to-face communication they and their families have been able to re-establish the physical proximity with longed-for people.

As to Arif's and Jamal's families, the closest interaction with anyone of the Syrian kin (all of whom reside in the homeland) remains the audio-video communication from distance. Although all the four families have created a pattern for maintaining family/kin ties via the ICTs, they still hope they would be able to return and to be physically co-present "there" again. In this respect, this is how Jasmin and Jamal thought of this moment at the time of our conversation. 
In 2018 we intend to have a wedding reception in Syria, if there is peace at last. It is mainly because of our Syrian relatives; they would like to see me as a bride ... We did not [have an official wedding reception] when we got married here, because they [the Syrian kin] couldn't attend, and I just didn't feel like it ... but there, the Syrian kin is very united, they would [appreciate it]. (Personal communication 2016)

The partners' desire was not to have only the wedding reception, but also to create a special memory of being with the longed-for people and to have the long-awaited family/kin reunion. However, in 2018 the couple celebrated their twentieth wedding anniversary "here" again without their Syrian relatives.

In this context, all of my interlocutors have been asking themselves the following question: Is meeting in a third country going to be the only way for physical co-presence with the kin in the foreseeable future?

\section{ACKNOWLEDGEMENTS}

The main ethnographic data regarding the bigger five-year-long study was gathered within my dissertational study "Immigration and Mixed Families (between Bulgarians and Immigrants from the Middle East and North Africa)" (2015-2017). However, I have also been considering the topic of bi-cultural and cross-national families within the scope of the ongoing project "Cultural Adaptation and Integration of Immigrants in Bulgaria" (DN 20/8), supported by the National Science Fund of Bulgaria (since 2018).

\section{NOTES}

1 During the socialist period there was a bilateral cultural cooperation agreement between Middle Eastern and African countries (Tsonev 1999: 107-108, 111, 270-271; Filipova 2009: 323-324; 326-327; Pileva 2017: 47-62).

2 The names used in the text are fictional. They are chosen from the names typical for the respective culture, but do not correspond with the interlocutors' birth names.

3 This also refers to the language. Irena, Svetla, and Jasmin are proficient in Syrian Arabic. They acquired it while living "there" and have been maintaining it ever since with the relatives and at work. Magda, however, as well as most of the children, who have some passive knowledge of their father's mother tongue, have been using English. An exception is the daughter of the third family, for whom Arabic became one of the professionally used languages. 
${ }^{4}$ It is the Arabic word for 'festival'. In particular, it refers to Eid al-Fitr (the end of the holy month of Ramadan), and Eid al-Adha (the end of the annual pilgrimage to Mecca, a.k.a. the Hajj).

5 Visits to Bulgaria by some Syrian family/kin members, particularly male siblings, and in one of the cases also the parents, were also registered. However, they were sporadic and took place mostly in the 1980s and the first half of the 1990s. In the cases of Asif, Fayyaz, and Jamal, this was the time before their moving (back) to Syria and the establishment of a routine manner of traveling to "there". As to Arif's brothers, they discontinued their visits to Bulgaria (which had been quite often considering the other cases) in the middle of the 1990s, when the level of the (organized) crime drastically increased, and they as foreign tourists no longer felt safe "here".

${ }^{6}$ Considering the general study, the lack or the rare virtual communication between the adult offspring of mixed descent and the non-Bulgarian parent's kin is not the usual case.

7 Thanks to the brother's migration to Sweden, Asif and Svetla also settled there.

\section{SOURCES}

Interview materials from $2016-2019$ in possession of the author.

\section{REFERENCES}

Baldassar, Loretta 2008. Missing Kin and Longing to Be Together: Emotions and the Construction of Co-presence in Transnational Relationships. Journal of Intercultural Studies, Vol. 29, No. 3, pp. 247-266. http://dx.doi.org/10.1080/07256860802169196.

Baldassar, Loretta 2015. Guilty Feelings and the Guilt Trip: Emotions and Motivation in Migration and Transnational Caregiving. Emotion, Space and Society, Vol. 16, pp. 81-89. http://dx.doi.org/10.1016/j.emospa.2014.09.003.

Baldassar, Loretta \& Baldock, Cora V. \& Wilding, Raelene 2007. Families Caring Across Borders: Migration, Ageing and Transnational Caregiving. New York: Palgrave MacMillan.

Baldassar, Loretta \& Nedelcu, Mihaela \& Merla, Laura \& Wilding, Raelene 2016. ICTBased Co-Presence in Transnational Families and Communities: Challenging the Premise of Face-to-Face Proximity in Sustaining Relationships. Global Networks, Vol. 16, No. 2, pp. 133-144. http://dx.doi.org/10.1111/glob.12108.

Boden, Deirdre \& Molotch, Harvey L. 1994. The Compulsion to Proximity. In: Roger Friedland \& Deirdre Boden (eds.) NowHere: Space, Time and Modernity. Berkeley \& Los Angeles \& London: University of California Press, pp. 257-286.

Breger, Rosemary \& Hill, Rosanna (eds.) 1998. Cross-Cultural Marriage: Identity and Choice. Oxford: Berg. 
Cottrell, Ann B. 1990. Cross-National Marriages: A Review of the Literature. Journal of Comparative Family Studies, Vol. 21, No. 2, pp. 151-169. http://dx.doi.org/10.3138/ jcfs.21.2.151.

Edwards, Rosalind \& Caballero, Chamion \& Puthussery, Shuby 2010. Parenting Children from 'Mixed' Racial, Ethnic and Faith Backgrounds: Typifications of Difference and Belonging. Ethnic and Racial Studies, Vol. 33, No. 6, pp. 949-967. http:// dx.doi.org/10.1080/01419870903318185.

Filipova, Nadya 2009. Balgariya izgrazhda kulturni i obrazovatelni mostove sas Siriya (sredata na 50-te - sredata na 60-te godini na XX vek). [Bulgaria Builds Cultural and Educational Bridges with Syria (The Mid-Fifties - the Mid-Sixties of the 20th Century).] Problemi i predizvikatelstva na arkheologicheskite i kulturnoistoricheskite prouchvaniia. [Problems and Challenges of Archaeological and Cultural-Historical Studies.] Vol. 2. Plovdiv: Universitetsko izdatelstvo Paisii Khilendarski, pp. 320-331.

Glick Schiller, Nina \& Basch, Linda \& Blanc-Szanton, Cristina 1992. Towards a Definition of Transnationalism: Introductory Remarks and Research Questions. In: Linda Basch \& Nina Glick-Schiller \& Cristina Blanc-Szanton (eds.) Towards a Transnational Perspective on Migration: Race, Class, Ethnicity, and Nationalism Reconsidered. New York: New York Academy of Sciences, pp. ix-xiv. https://doi. org/10.1111/j.1749-6632.1992.tb33482.x.

Hooks, Bell 1991 [1990]. Yearning: Race, Gender and Cultural Politics. London: Turnaround.

Licoppe, Christian 2004. "Connected" Presence: The Emergence of a New Repertoire for Managing Social Relationships in a Changing Communication Technoscape. Environment and Planning D: Society and Space, Vol. 22, No. 1, pp. 135-156. https://doi.org/10.1068\%2Fd323t.

Licoppe, Christian \& Smoreda, Zbigniew 2005. Are Social Networks Technologically Embedded? How Networks Are Changing Today with Changes in Communication Technology. Social Networks, Vol. 27, No. 4, pp. 317-335. https://doi.org/10.1016/j. socnet.2004.11.001.

Lopez, M. Nakamura 2017. Mixed Family Life in the UK: An Ethnographic Study of Japanese-British Families. Cham: Springer International Publishing.

Mahler, Sarah J. 2001. Transnational Relationships: The Struggle to Communicate across Borders. Identities, Vol. 7, No. 4, pp. 583-619. http://dx.doi.org/10.1080/1 070289X.2001.9962679.

Markov, Ivaylo 2019. Changing Practices of "Being Together" in the Transnational Kin-Relationships among Gorani. Bulletin of the Institute of Ethnography SASA, Vol. 67, No. 3, pp. 501-522. https://doi.org/10.2298/GEI1903501M.

Mason, Jennifer 2004. Managing Kinship over Long Distances: The Significance of 'The Visit'. Social Policy and Society, Vol. 3, No. 4, pp. 421-429. https://doi.org/10.1017/ S1474746404002052.

Nedelcu, Mihaela \& Wyss, Malika 2016. 'Doing Family' through ICT-Mediated Ordinary Co-Presence: Transnational Communication Practices of Romanian Migrants in Switzerland. Global Networks, Vol. 16, No. 2, pp. 202-218. https://doi.org/10.1111/ glob.12110. 
Nguyen, Thu Huong \& King, Brian 2002. Migrant Communities and Tourism Consumption: The Case of the Vietnamese in Australia. In: C. Michael Hall \& Allan M. Williams (eds.) Tourism and Migration: New Relationships between Production and Consumption. Dordrecht, Netherlands: Kluwer Academic Publishers, pp. 221-240. https://doi.org/10.1007/978-94-017-3554-4_12.

Petridou, Elia 2001. The Taste of Home. In: Daniel Miller (ed.) Home Possessions: Material Culture behind Closed Doors. Oxford \& New York: Berg, pp. 87-104. Available at https://is.muni.cz/el/1423/jaro2016/SAN107/um/MILLER_Home_Possessions. pdf, last accessed on 5 December 2019.

Pileva, Desislava 2017. Images of 'Our Foreign Friends': Representations of Students from the Middle East and Africa in the Bulgarian Newspaper 'Student's Tribune' (1960s-1970s). Anthropology, Vol. 4, pp. 47-62. Available at https://www. researchgate.net/publication/335821391, last accessed on 5 December 2019.

Rapport, Nigel \& Andrew Dawson 1998. Home and Movement: A Polemic. In: Nigel Rapport \& Andrew Dawson (eds.) Migrants of Identity: Perceptions of Home in a World of Movement. Oxford \& New York, NY: Berg, pp. 19-38.

Stephenson, Marcus L. 2002. Travelling to the Ancestral Homelands: The Aspirations and Experiences of a UK Caribbean Community. Current Issues in Tourism, Vol. 5, No. 5, pp. 378-425. https://doi.org/10.1080/13683500208667932.

Svašek, Maruška 2008. Who Cares? Families and Feelings in Movement. Journal of Intercultural Studies, Vol. 29, No. 3, pp. 213-230. https://doi. org/10.1080/07256860802169170.

Tsonev, Kiriak 1999. B"lgaro-arabskite otnosheniia. [Bulgarian-Arabic Relations.] Sofia: Paradigma.

Urry, John 2002. Mobility and Proximity. Sociology, Vol. 36, No. 2, pp. 255-274. https:// doi.org/10.1177\%2F0038038502036002002.

Urry, John 2003. Social Networks, Travel and Talk. British Journal of Sociology, Vol. 54, No. 2, pp. 155-175. https://doi.org/10.1080/0007131032000080186.

Vertovec, Steven 2004. Cheap Calls: The Social Glue of Migrant Transnationalism. Global Networks, Vol. 4, No. 2, pp. 219-224. https://doi.org/10.1111/j.14710374.2004.00088.x.

Vinea, Ana 2007. Creating Families across Boundaries: A Case Study of Romanian / Egyptian Mixed Marriages. New York: The American University in Cairo Press.

Wilding, Raelene 2006. "Virtual" Intimacies? Families Communicating across Transnational Contexts. Global Networks, Vol. 6, No. 2, pp. 125-142. https://doi. org/10.1111/j.1471-0374.2006.00137.x.

Desislava Pileva is Assistant Professor (PhD) at the Institute of Ethnology and Folklore Studies with Ethnographic Museum, Bulgarian Academy of Sciences, Bulgaria. Her main research areas are transnational and internal migrations and mobility, and mixed families and intercultural interactions.

desislava.pileva@iefem.bas.bg 